\section{DIGITAL COMMONS \\ @ UNIVERSITY OF SOUTH FLORIDA}

\section{ABO: Interactive Journal for Women in the Arts, 1640-1830}

Volume 8

Issue 2 Volume 8, Issue 2 Fall 2018

Article 5

2018

\title{
Review of Charlotte Lennox: An Independent Mind by Susan Carlile
}

\author{
Alexis McQuigge \\ University of Regina, alexis.mcquigge@uregina.ca
}

Follow this and additional works at: https://digitalcommons.usf.edu/abo

Part of the Dramatic Literature, Criticism and Theory Commons, Educational Methods Commons, Feminist, Gender, and Sexuality Studies Commons, and the Literature in English, British Isles Commons

\section{Recommended Citation}

McQuigge, Alexis (2018) "Review of Charlotte Lennox: An Independent Mind by Susan Carlile," ABO:

Interactive Journal for Women in the Arts, 1640-1830: Vol.8: Iss.2, Article 5.

https://doi.org/10.5038/2157-7129.8.2.1203

Available at: https://digitalcommons.usf.edu/abo/vol8/iss2/5

This Reviews is brought to you for free and open access by Digital Commons @ University of South Florida. It has been accepted for inclusion in ABO: Interactive Journal for Women in the Arts, 1640-1830 by an authorized administrator of Digital Commons @ University of South Florida. For more information, please contact digitalcommons@usf.edu. 


\title{
Review of Charlotte Lennox: An Independent Mind by Susan Carlile
}

\begin{abstract}
This article reviews Susan Carlile's recent biography of Charlotte Lennox, Charlotte Lennox: An Independent Mind. Because much of Lennox's life story, and many of her works, remain mysterious to contemporary readers, Carlile's work highlights some unique and important aspects of the life of a - at least in the eighteenth- and nineteenth-centuries, a celebrated literary minds. Carlile's work is an important and necessary addition to the study of women's writing in the period, and contributes a great deal to those studying the works of Charlotte Lennox.
\end{abstract}

\section{Keywords}

Charlotte Lennox; Review; Translations; Novels; biography

Creative Commons License

(c) (1) (9)

This work is licensed under a Creative Commons Attribution-Noncommercial 4.0 License 
Review of Carlile, Susan. Charlotte Lennox: An Independent Mind. Toronto: University of Toronto Press, 2018. xxvi + 466 pp. Index. ISBN: 9781442626232

Reviewed by Alexis McQuigge

University of Regina, Saskatchewan

Susan Carlile's biography of Charlotte Lennox begins simply, and at what must have seemed among the most daunting of moments of Lennox's career: "Twenty-two-year-old Charlotte Lennox stood at an imposing front door. Before her was the stately home of a powerful man" (3). That man, readers learn, is Samuel Richardson, and "his influence could make the difference between paying the rent in the space she shared with her unreliable husband ... or having to once again slip away in the night because they could not pay their bills" (3). The story of Lennox's courage and her financial desperation, begun in the earliest pages of Carlile's biography, continues throughout her thorough examination of Lennox's life and work, and illustrates the struggles that Lennox, and authors like her, lived with in trying to make a living in the eighteenth century. Indeed, among the most interesting things in a text filled with interesting moments is the way that Carlile's work teaches her readers that successful-even famedauthorship did not necessarily equate to financial security in the eighteenth century. Even an author as prolific and as acclaimed as Lennox could spend the bulk of their life living in nearabject poverty.

Unfolding in three sections ("The American," "The Professional," and "The Celebrity") of four chapters each, Carlile's work examines Lennox's life beginning with her childhood in America and continues through her adulthood as a "literary and cultural critic, a novelist, an editor, a translator, a poet, a playwright, a naturalist, a philosopher, and a proto-feminist" (4). Organized according to phases in Lennox's life, the biography addresses Lennox's childhood and teenage years, as well as her early life as a writer (covered in chapters 1-4,) her later literary productions (discussed in chapters 5-8) and, finally, her family life and celebrity (the subject of chapters 912). A common theme throughout, however, is that, in the realm of eighteenth-century literary production, there seems to be nary a genre to which Lennox did not put pen. Though she is bestknown to modern readers as the author of The Female Quixote (1752), (the subject of chapter 4, "Uniting the Laudable Affections of the Mind,") Lennox was famed in the Eighteenth and Nineteenth centuries as the mind behind Shakespeare Illustrated (1753), a study of Shakespeare's source material that, ultimately, finds him wanting in originality, discussed at length in chapter 5, "Debating Genius." The brilliance behind Carlile's work lies, in fact, in its ability to highlight that the Charlotte Lennox long studied by scholars as a novelist was also "publicly revered as a respected female intellectual" (206) in an age where women were actively discouraged from entering the literary marketplace at all, let alone with works of literary criticism.

Beginning with Lennox's childhood in America (the likely inspiration for her first novel, The Life of Harriet Stuart, Written by Herself [1751] and her final novel, Euphemia [1787]), Carlile's work traces the evolution of a literary genius that most casual readers, and many academics, will find unfamiliar. Readers may know of Lennox's friendship with Samuel Johnson but may be less familiar with her time spent with Lady Isabella Finch and Lady Mary Rockingham in her youth, the subject of chapter two, "An English Sappho," or with their intentions to gain Lennox an 
appointment at court as a companion to "one of the princesses" (40). While some may see in those friendships Lennox's golden ticket, Carlile makes clear that Lennox did not see fulfillment in royal companionship. Instead, first with her poetical works and then with Harriet Stuart, Lennox launched a successful—if financially unstable_-literary career.

As with many female writers of the period, the academic searching for biographical information may find their search somewhat unrewarded, but Carlile's research is as complete and thorough as possible considering so many of Lennox's works have fallen out of scholarly conversation in the twentieth and twenty-first centuries. Readers curious about epistolary history might wish for more information on a set of Lennox's letters that Carlile briefly mentions were found in a Scottish safe deposit box in 1964 (What did they say? Why were they there? How did they get there?) but most will find that her research is impeccable. There is no reason not to expect that Carlile's work, which is a radical and necessary update to Miriam Small's 1935 biography, as well as the works of others in the interim, will become the standard source for those studying Lennox's work in the future.

One of the strengths of Carlile's work is in the refusal to focus on Lennox's relationships with famous male writers and instead to discuss the remarkable moments when she serves as her own advocate, including when she took on the role of editor to the men who helped her translate a fraction of the twenty-five plays she chose to include in The Greek Theatre of Father Brunoy (1760). This work made Greek plays much more accessible to an English audience, and as discussed in chapter six, "Prospering in a Patronizing Profession," Lennox was lauded for her skill as a translator. Indeed, that Lennox could even gain access to these men - let alone press them into service - signals the extent of her influence. That Carlile chooses not to name most of them is a key moment in the development of her characterization of Lennox as an "Independent Mind." Clearly, despite her oft-mentioned prickliness and her criticism of Shakespeare, which Carlile suggests reads like the work of an "angry and ungenerous curmudgeon" (112) Lennox's genius was well-respected.

If this hefty biography has a scanty element, it is in the discussion of Lennox's personal life, which is the focus of chapter eleven, "Family, Marriage, and Motherhood." Because there is "very little biographical information" available with which to develop a more "private" notion of who Lennox was, it is difficult to get a sense of her as a person (18). As Carlile notes, Lennox "was not a scandalous female author, a constrained woman, a religious devotee, or a country isolate" (18). This lack of scandal is, admittedly, unfortunate for those who relish literary gossip, but what emerges in the place of scandal is integral to the study of women's lives in the eighteenth century. Because she lacked both the reputation and the prestige of some of her contemporaries, and because Lennox forged her own path with her respected scholarly translations and editions, we can learn a great deal about what a literary woman without advantage did to make her work stand out. Lennox's shiftless husband, her ill health (especially her eye trouble), her constant need to move to avoid creditors, her tumultuous relationships with various members of the aristocracy, and her humble beginnings can teach us a great deal about how women without means but with intellectual and literary aspirations negotiated life in eighteenth-century England. Indeed, it is this picture of the struggling but genius Lennox that leaves the strongest impression of Carlile's work. 
In sum, Carlile's book is not just a triumph, but a timely and necessary one that will greatly influence not just the academic reader hypothesizing about the Lennox's work, but also the curious reader's knowledge of female agency and literary production in the eighteenth century. 